M. Bourourou', orcid.org/0000-0002-5055-0858,

A. Bouzenzana ${ }^{2}$, orcid.org/0000-0003-0440-9471, T. Batouche ${ }^{1}$, orcid.org/0000-0002-1813-5590, A. Benselhoub ${ }^{3}$, orcid.org/0000-0001-5891-2860
1 - Laboratory of Mining, Larbi Tebessi University, Tebessa, Algeria, e-mail: m.bourourou@univ-tebessa.dz 2 - Larbi Tebessi University, Tebessa, Algeria

3 - Environmental Research Center CRE, Annaba, Algeria

\title{
COMPOSITION AND PROCESSING OF SULPHIDE LEAD-ZINC ORES FROM CHAABET EL-HAMRA MINE (SETIF, ALGERIA)
}

Purpose. In order to fully exploit the metal and facilitate its method of processing, we need an accurate knowledge of its composition, granular distribution, and association with unimportant and penalizing elements that we would like to get rid of, compared to the distribution of the element to extract by flotation method.

Methodology. The present experimental work proposes an approach to the mineralogical, chemical and particle size characterization, several analyzes have been carried out by Scanning Electron Microscopy with Energy Dispersive Spectroscopy (SEM/ EDS), X-ray Diffraction (XRD), Optical Microscopy (OM), Particle Size-Fraction Analysis (PSFA), and X-ray Fluorescence (XRF). These analyzes were submitted on samples of lead-zinc of different sizes as well as well-prepared fine powder of this ore; the zinc content of the raw material is about $5 \% \mathrm{Zn}$.

Findings. The results obtained by the mineralogical characterization and the particle size analysis reveal a very varied and irregular texture of the ore, consisting mainly of sulphides (sphalerite, galena, pyrite, marcasite), associated with carbonate gangue, mainly dolomite and calcite. The theoretical dimensions of the particles found in the fine grain size classes [ $-1+0.053] \mathrm{mm}$. In addition, the conditions of the pulp using the following reagents: $\mathrm{CuSO}_{4}$ activator, $\mathrm{PAX}$ collector, $\mathrm{CaO}$ regulator and the pine oil foamed, along with a $\mathrm{pH}$ modifier between 10.5 and 12 (11.8 optimal), improve the content of sulphide minerals, and increased the concentrate of sphalerite $(\mathrm{ZnS})$ by foam Flotation with a maximum recovery and economically appropriate content $(54 \% \mathrm{Zn}$ concentrate).

Originality. Depending on the results of the analysis performed and the complete collection of data obtained in the laboratory, we aim to optimize the process of treating lead-zinc sulphide ore and give a more detailed reference source to specialists, researchers and metallurgists in field of mining in general and in the treatment of polymetallic lead-zinc ore in the area studied in particular.

Practical value. Benefit the values of beneficial minerals (concentrate of zinc and others sulphide), from different types of raw materials. The latter focuses on flotation as the main successful technique in the extraction of this type of lead-zinc minerals, but it requires constant research and careful examination of its elements and values in order to excel in this field of polymetallic-sulphide ore processing.

Keywords: lead-zinc ore, SEM/EDS analyses, sphalerite, flotation, mineral processing, optimization

Introduction. Among the most abundant metals in the world, lead and zinc are two important metal resources of non-ferrous metals [1]. Due to their special physicochemical properties, they are more commonly and widely used in automotive industries, metallurgical industry, chemical industry, mechanical industry, pharmaceutical industry, as well as in the areas of construction and other fields of electronics [2]. Sphalerite and zinc oxide are the main minerals containing zinc [3]. They are generally found in association with other sulphide minerals and useful components such as galena, pyrite, chalcopyrite and other valuable minerals $[4,5]$.

All over the field of mining, the development trend is to separate and process low grade ores with complex mineralogy, many mining operations process sulphide ores to extract various precious minerals, in order to meet the required specifications of the concentrates for extraction of metals [6]. When developing a treatment process for the upgrading of this type of $\mathrm{Pb}-\mathrm{Zn}$ ores, one requires a very detailed assessment of the appropriate separation method and other variables related to the experimental approach used, which are very important [7]. Due to improved efficiency and product development, the recovery as well as the selectivity of the separation of minerals containing lead and zinc, are strongly influenced by the mineralogical, chemical characteristics of the ore and various parameters of the enrichment process [8]. In accordance with this regard, most of the $\mathrm{Pb}-\mathrm{Zn}$ sulphide ore is processed by flotation, which depends on several parameters such as, the $\mathrm{pH}$ of the pulp, the particle size distribution of the feed, the depressant, the frother, the collector, activator, regrinding of

(c) Bourourou M., Bouzenzana A., Batouche T., Benselhoub A., 2021 rougher concentrates, as well as other parameters related to the types of materials used [9].

In Algeria, mining is well-known and has existed since ancient times, but its importance increased during the $20^{\text {th }}$ century due to the growing demand and the great need for minerals to meet extensive use in various fields [10]. Many lead and zinc deposits are located in the northeast of the country to cover these needs. It should be noted, however, that the extraction and enrichment process suffers from many problems that hinder the provision of the required quantity and quality to meet the needs of the consumer at once. This, in fact, applies to the case of our study.

In the absence of a characterization reference of the sulphide lead-zinc ore of Chaabet El-Hamra, and for the purpose of examining the smallest details of the crude ore and deepening the analysis of its structural properties, our study presents a set of characterizations of the physical and chemical as well as mineralogical study on thrust, including the analyses to the microscopes optical (MO) and scanning electron (SEM), analysis of $\mathrm{X}$-ray diffraction (XRD), the analysis of particle size distribution (PSFA) and the analysis in the X-ray fluorescence (XRF). These characterizations were performed on samples collected and carefully prepared (powder, cut thin and polished section) to maintain the representativeness of the results. The results obtained allowed us to establish sources of reliable knowledge about the ore, lead-zinc, develop and improve the method for processing Lead-Zinc sulphide ore by flotation, and adapt to the best conditions of the pulp (reagents, $\mathrm{PH}$, percentage solid/liquid, operation time, aeration), in order to achieve the required quality of the product zinc treated (more than $50 \% \mathrm{Zn}$ ), specified and conditioned by the extractive metallurgy of zinc. 
Identification of the deposit. Chaabet El-Hamra deposit is located, in the Chouf-Bouarket region; $4.5 \mathrm{~km}$ from Ain-Azel and $12 \mathrm{~km}$ to the southeast of Kherzet Youssef mining processing plant, rectilinearly, approximately $50 \mathrm{~km}$ to the south of the province of Sétif and $250 \mathrm{~km}$ to the south-east of Algiers. The approximate geographic coordinates of Chaàbet ElHamra are: $35^{\circ} 45^{\prime} \mathrm{N}$ and $5^{\circ} 30^{\prime} \mathrm{E}$. The region's climate is semiarid, cold in winter and hot in summer. The site altitude ranges from 950 to 1200 meters. The average annual precipitation is $322 \mathrm{~mm}$ and rarely exceeds $500 \mathrm{~mm}$. The average annual temperature is $15^{\circ} \mathrm{C}$.

Regional geology. The study area is located in the district of Hodna, as part of the the Foreland of the Alpine range of eastern Algeria, at the junction of three geological zones (Tellian Atlas, Saharan Atlas and high plains). The high plains cover a carbonate platform, which includes more than $2300 \mathrm{~m}$ of terrigenous-carbonate sediments. This platform remained shallow during the Mesozoic times. It was unstable and diminished from Upper Triassic to Albian (Lower Cretaceous). Several dolomitic series are characterized by their significant mineralization, mainly on the northern and southern margins of the platform [11].

Deposit mineralization. The mineralization of Chaabet ElHamra deposit is observed in multi-layered structure bundles, in the form of mineralized lenses of both; monomineral and maltimineral compositions. The global metalliferous zone, which is composed of lenses, is in the form of a wide band in the north-west direction, where the size is about $2700 \mathrm{~m}$ length; 300-600 m width and 100-400 m depth.The main minerals in this composition are sphalerite, pyrite and marcasite. The secondary minerals are galena, hematite. The gangue minerals associated with mineralization are calcite, baryte, dolomite and more rarely quartz and gypsum. The oxidizedore minerals are mainly smithsonite, cerusite, and limonite. The thickness of the mineralized zone ranges from 1 to $20 \mathrm{~m}$. The mineralized zone is accessed via an inclined (decline) shaft, which is located at the lowest point in the region, over a length of $830 \mathrm{~m}$ in waste rock. This shaft is used for the movement of personnel and equipment and the evacuation of ore. It is also used to deliver fresh air in underground mines. This decline is preceded by a trench access, a length of $113 \mathrm{~m}$, from the coast 1034 to that of 1025 , but a slope contrary to the slope of the descent, is of the order of $6 \%$. The ore extracted from Chaabet El-Hamra mine was trucked to the mining complex at Kherzet Youcef. It could be then transformed into zinc concentrate [12]. The mineralization of the Chaabet El Hamra deposit is mainly composed of:

1. The mineralization of sphalerite, pyrite, marcasite and rarely galena is intimately linked to the Hauterivian dolomite rocks, by locating independently at the tectonic structures affecting the level of mineralization.

2. The zinciferous mineralization occurs in lenticular layers, grouped in two stratiform bundles, separated by the sterile whitish dolomite bank of $6 \mathrm{~m}$ of power.

3. The Galena is very rare, and generally develops at the ends of the lenses, limiting the zinciferous zone from that of baryto-pyritiferous; and there are several varieties of sphalerite including: massive, recrystallization, crack, and breccia, which constitute the bulk of the industrial ore.

Material and method. Physical preparation and sampling. For successful and complete laboratory work, careful consideration of sample preparation and adherence to the conditions of each experiment is required. In this distinctive framework of our work, there is a sample of $70 \mathrm{~kg}$ of lead-zinc ore from the Chaabet El-Hamra mine, Ain Azel-Setif province, Algeria. The dimensions of the pieces are less than $35 \mathrm{~cm}$, they are subjected to the mechanical preparation process to completely free the mineral particles (mesh size between 63 and $100 \mu \mathrm{m}$ ) in order to facilitate their extraction and increase the recovery rate of the desired product. This preparation process goes through several crushing stages and then grinding stages. A few rocks of dimension less than $10 \mathrm{~cm}$ are chosen and kept for macroscopic and microscopic observations (preparation of thin sections and polished sections. In addition, a homogenization and quartering technique is applied after the mechanical treatment of the run-off, to produce a batch of ore with a well-defined and irregular particle size distribution. The resulting batch division is done in parallel with the desired experiment. Of which, a quantity of the latter subjected to physical, chemical and mineralogical analysis; a second quantity is kept for enrichment trials. We undergo proper preservation and storage of all samples obtained in accordance with the usual conditions of the experiments scheduled during this work.

Particle size analysis. The analysis of the particle size distribution of the grains is carried out in a vibrating sieve shaker from the AUTOMATIC SIEVE SHAKER D407 type CONTROLS AUTOMATIC group. A standard series of sieves with dimensions: $(10,8,4,2,1,0.5,0.25,0.125$ and 0.053$) \mathrm{mm}$, is used for products of coarse size. As well as a series of micro size sieves: (100, 80, 63 and 37 micron), for crushed ore. For each experiment, samples (previously dried at $105{ }^{\circ} \mathrm{C}$, for 24 hours) in an amount of $1000 \mathrm{~g}$ are used, the sieving time is set at 20 minutes. The mass of residue and pass from each sieve are weighed using an extremely precise balance. The results obtained are presented in Table1 and also graphically in Fig. 1.

Chemical composition analysis. Several representative samples ( 15 to $20 \mathrm{~g} / \mathrm{sample}$ ) are prepared in pellets and analyzed for chemical composition, which is carried out by X-ray fluorescence (X-ray) using dispersion microscopy, model RIGAKU ZSX PRIMUS IV (WDXRF), within the Elegant Materials Research Unit (EMRU), Ferhat Abbas University Setif, which reveal the results illustrated further (Table 2).

Mineralogical characterization. Thirty six (36) representative samples (mineral powder, thin sections and polished sections) were examined during this study to properly identify and quantify the minerals composing the rock studied. To this end, two microscopic observation techniques are carried out on the ore surface, including:

Optical microscopy (om) analysis. This analysis was performed on several samples (polished section) using a group optical microscope [NIKON] type [ECLIPSE LV150NL] of a camera type [DS-U3 Digital Camera Control Unit], within the laboratory of the National School of Mining and Metallurgy (ENSMM), Annaba, allowing the capture of photos, which showed the presence of the minerals presented by (further in the text, Fig. 4).

Scanning electron microscope (sem) analysis. The SEM analysis of ore from Chaabet El-Hamra lead-zinc mine was

Table 1

Particle size analysis results

\begin{tabular}{|c|c|c|c|c|}
\hline & & & Yiel & (\%) \\
\hline Size cl & $\operatorname{ses}(\mathrm{mm})$ & Weight (g) & & \\
\hline-10 & +8 & 81.90 & 8.19 & 100 \\
\hline-8 & +4 & 290.30 & 37.22 & 91.81 \\
\hline-4 & +2 & 156.50 & 52.87 & 62.78 \\
\hline-2 & +1 & 112.70 & 64.14 & 47.13 \\
\hline-1 & +0.5 & 84.10 & 72.55 & 35.86 \\
\hline-0.5 & +0.25 & 71.80 & 79.73 & 27.45 \\
\hline-0.25 & +0.125 & 73.50 & 87.08 & 20.27 \\
\hline-0.125 & +0.053 & 81.00 & 95.18 & 12.92 \\
\hline-0.053 & +0 & 48.20 & 100 & 4.82 \\
\hline & tal & 1000 & & \\
\hline
\end{tabular}




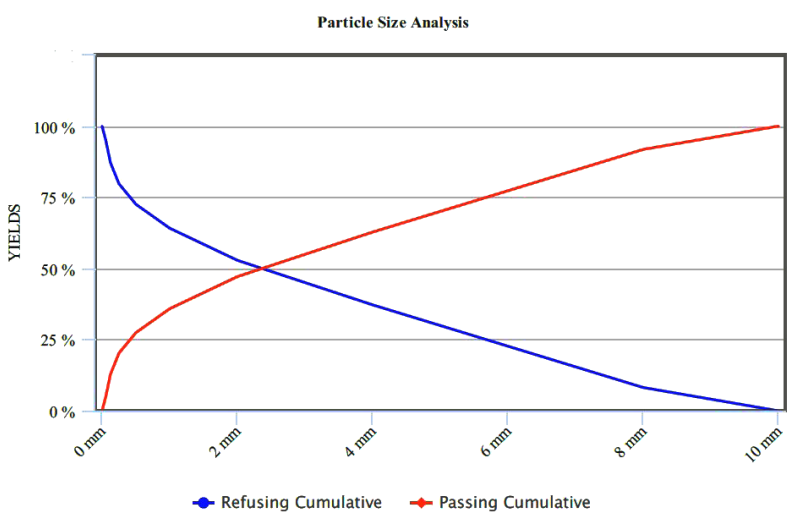

Fig. 1. Particle size analysis curves

carried out using a scanning electron microscope, type [QUANTA 250], using dispersive spectroscopy energy (EDS).

The mineralogical characterization carried out is followed by a technique of analysis of mineral phases by: X-ray diffraction (xrd) analysis. This analysis is subjected to samples of very fine mineral powder, $(10 \mathrm{~g} / \mathrm{sample})$, representative and homogeneous. Using [PRO PAN Analytical] diffractometer, model [MPD EXPERT, RTMS detector, SPENER sample platform, Cu tube, $\lambda=1.5405 \AA$. The results obtained are presented below (further in the text, Fig. 8).

Flotation methode. During zinc processing and production, most multi-metal lead-zinc sulphide ores are processed by foam flotation [13, 14]. This process depends on the difference in hydrophobicity on mineral surfaces, the latter may increase due to the collector, or the hydrophobic particles attach more easily to the interface of the bubble than the hydrophilic particles [15]. Under well-determined $\mathrm{pH}$ conditions, the use of non-toxic reagents such as $\mathrm{ZnSO}_{4}$ (depressant), $\mathrm{CuSO}_{4}$ (activator), EXP (collector), have provided positive results for flotation of polymetallic sulphide ore of $\mathrm{Pb}-\mathrm{Zn}$. Sphalerite is the most important mineral in the production of zinc, from which over $85 \%$ of zinc is produced, during the separation of sphalerite by foam flotation. An understanding of depression, activation and Sphalerite flotation is therefore very important in theoretical and practical research on lead-zinc sulphide minerals.

In our present work, we undertake a study on the effects of various parameters of the foam flotation process on the concentration of typical samples of lead-zinc ore, and determine the influence of the main operating variables on the efficiency of separate gangue elements (mainly carbonates) from the desired elements (sulphide).

Flotation kinetics and conditioning. The lead-zinc samples used in this work are collected in the mining district of Ain Azel, Setif province. Then, they are subjected to a series of preparations until the complete release of the constituents (obtaining the optimal mesh). After, homogenization is followed

Table 2

Result of particle size and chemical analysis of lead-zinc ore samples after crushing

\begin{tabular}{|c|c|c|c|c|}
\hline $\begin{array}{l}\text { Size classes } \\
\quad(\mathrm{mm})\end{array}$ & $\begin{array}{l}\text { Weight } \\
\text { (g) }\end{array}$ & $\begin{array}{l}\text { Yields } \\
(\%)\end{array}$ & $\begin{array}{l}\mathrm{Zn} \\
(\%)\end{array}$ & $\begin{array}{l}\mathrm{Pb} \\
(\%)\end{array}$ \\
\hline+0.1 & 4.20 & 2.10 & 5.36 & 0.86 \\
\hline$-0.1+0.08$ & 47.00 & 23.5 & 8.09 & 0.81 \\
\hline$-0.08+0.063$ & 109.10 & 54.55 & 10.05 & 0.82 \\
\hline$-0.063+0.040$ & 28.30 & 14.15 & 7.76 & 0.79 \\
\hline-0.040 & 11.40 & 5.70 & 3.48 & 0.82 \\
\hline Total & 200 & 100 & 5.12 & 0.83 \\
\hline
\end{tabular}

by a series of divisions (quartering) until a representative sample of crushed ore $(\mathrm{d} 85=80 \mu \mathrm{m})$ is obtained in a laboratory ball mill, with a density of the wet grinding paste about $67 \%$. The flotation tests are performed in a DENVER flotation cell, of a volume of $2.5 \mathrm{~L}$, using a stirring speed of $1500 \mathrm{rpm}$ and a solid concentration of $1 / 3$ ratio (33\%); the ore powder is put in aqueous suspension, reagents are added to modify the surface properties of the particles with the aid of activator first, and then collectors, which are formed stable foams, parallel with time sufficient conditioning, and in a $\mathrm{pH}$ of the pulp adjusted and well determined. The choice of specific reagents for flotation of polymetallic sulphide ores is dictated by the mineralogical and particle size characterization of the ore, the efficiency of achieving the desired objectives and the costs of these reagents [16]. Regarding our work, and according to the terms of grade and recovery rate of recoverable elements, the flotation of sphalerite foam is carried out using Xanthate as sphalerite collectors, after activation by copper sulfate $\left(\mathrm{CuSO}_{4}\right)$. Activation of the sphalerite surface by copper will modify the properties of the surface, which leads to completely different adsorption behaviors from Xanthate. This activation of the $\mathrm{ZnS}$ surface can be explained by the substitution of zinc atoms at the surface using $\mathrm{Cu}^{2+}$ ions according to the following equation

$$
\mathrm{ZnS}_{(s)}+\mathrm{Cu}_{(a q)}^{2+} \rightarrow \mathrm{CuS}_{(s)}+\mathrm{Zn}_{(a q)}^{2+}
$$

The foaming agent used is pine oil. The $\mathrm{pH}$ of the pulp was kept between 11 and 12 with lime, which was used both as a $\mathrm{pH}$ regulator and as a depressant of pyrite existing in high proportions [17]. The contact time of the reagents with the pulp is set by: 3 minutes for the activator, and 4 to 5 minutes for the collector, within 5 minutes between each addition and the next. While the total flotation conditioning time before scraping the concentrate was set at 12 minutes. Particular attention is paid to the influence of the doses of certain reagents on the separation yields of sulphide minerals with carbonate gangues in a lead-zinc ore, based on the depression of carbonates and the flotation of sulphide minerals [18]. Among the important parameters that have a significant impact on improving mobility and flotation kinetics are the following:

1. Optimal grind fineness.

2. Reagents regime (dosages and positions of their addition in the flotation process)

\section{Pulp PH.}

Result and discussion. Particle size. The results of sieve analysis presented in Table 1 above show that a large majority of mass in the larger size fractions $(+250 \mu \mathrm{m})$, within; $[+8,+4$, $+2,+1$ and $+0.5 \mathrm{~mm}]$ of $72.55 \%$ (weighted 725.5 grams), which affirms the intensity of lead-zinc ore (approximately 4 on the Mohs scale). The other (distributed) quantities appear in the finer particle-size fractions $(-250 \mu \mathrm{m})$, within $[-0.25$; $+0.125 ;+0.053$ and $-0.053 \mathrm{~mm}]$ of $27.45 \%$ (weighted 274.5 grams).

Fig. 1 depicts a concave particle-size distribution curve, so that the material contains more coarse particles than fine particles. It also shows that the average dimension is between 3 and $2 \mathrm{~mm}\left(\mathrm{D}_{50}>2 \mathrm{~mm}\right)$. In addition, the latter fines $(-0.053 \mathrm{~mm})$ constitute only of $4.82 \%$ (weighted 48.2 grams) by the total mass of sieved samples. Therefore, this irregular distribution demonstrates the raw material specific hardness and formation.

Particle size and chemical analysis of grinding $\mathrm{Pb}-\mathrm{Zn}$ ore. After classification, a particle size and chemical analysis was carried out at the level of each size class, to specify the quantitative and qualitative aspect of the metalliferous elements sought ( $\mathrm{Zn}, \mathrm{Pb}$, and so on). This analysis is followed by an atomic absorption analysis, and also by an X-ray fluorescence analysis. The results obtained are detailed and presented in the following table (Table 2).

The results of the chemical analysis presented in the previous table indicate the importance of zinc content in fine par- 
ticle size classes [ $<80$ micron], but this content is consistently distributed in coarse classes. Based on these results, the heaviest fraction is in the $[0.08 ; 0.063] \mathrm{mm}$ range, represented by a maximum zinc content (about $10 \%$ ) and a weight efficiency of $54.55 \%$. (Figs. 6, $a, b$ ). In addition, lead content is somewhat low in almost all particle size classes $(<1 \%)$.

$\mathrm{X}$-ray diffraction of slices of different sizes (Figs. 2, 3).

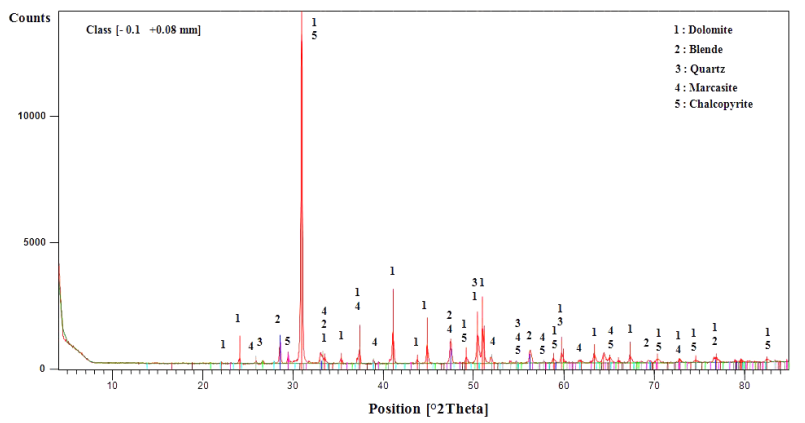

Fig. 2. X-ray Diffraction spectrum of size class $[-0.1+0.08 \mathrm{~mm}]$

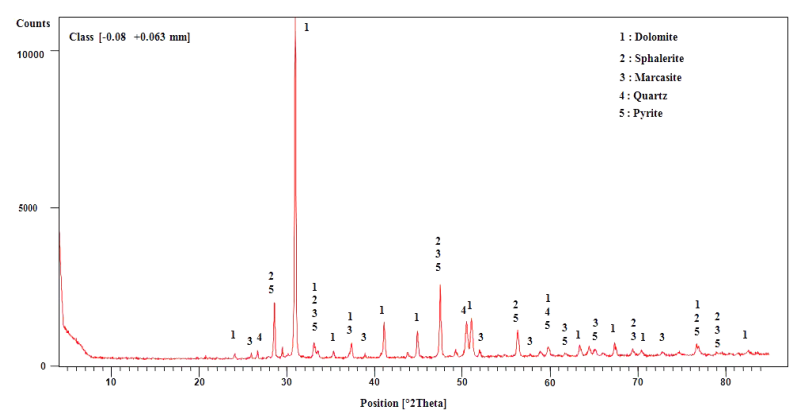

Fig. 3. X-ray diffraction spectrum of size class $[-0.08+0.063 \mathrm{~mm}]$

Mineralogical characterization. Optical microscopy (OM). The observation of the polished surfaces under an optical microscope in reflected light (natural light, polarized), allows capturing the following photos:

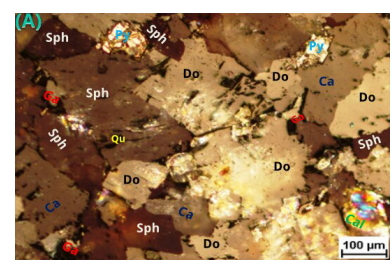

$a$

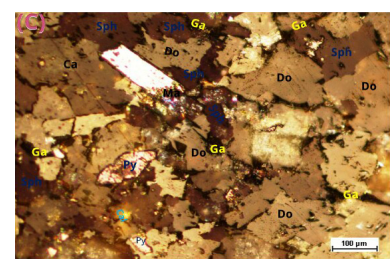

$c$
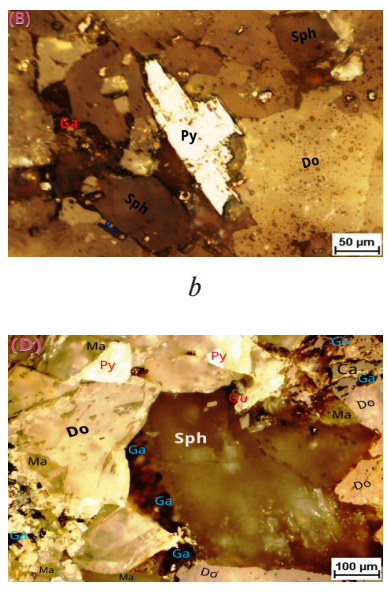

$d$
Fig. 4. Optical microscope image (polished section) showing the presence and association of different minerals. (Sph: sphalerite, Ga: galena, Py: pyrite, Dol: dolomite, Ca: calcite, Ba: baryte, Ma: marcasite, Cal: chalcopyrite and Qu: quartz)

(A) and (B): brown fine blende crystals grouped together and intercrystalline spaces filled with dolomite, calcite and pyrite.

(C) and (D): a combination of different crystal sizes has shown the presence of some minerals associated with sphaler- ite in large amounts, such as white galena with triangular pullouts, pale-yellow pyrite and other gangue minerals (mainly dolomite, quartz and lowercalcite volumes) as well as a large clear spot of sphalyrite in the middle of Fig. 4, D.

These photos showed the presence of the main sulphide minerals such as, blende, marcasite, pyrite, galena and chalcopyrite, such as small or medium size grains and sometimes space fillings or large crystals. Associated with carbonate minerals such as, dolomite, medium grained calcite and some stains of oxides and sulphates such as, barite, quartz and hematite.

Scanning electron microscopy/energy dispersive $\mathrm{X}$-ray (SEM/EDX) (Figs. 5, 6, 7).

Sample 1: a scanned area shows sphalerite as a predominant mineral with significant amounts of pyrite, marcasite, and traces of galena; Sample 2: scanned point, demonstrating marcasite as a predominant ore with traces of sphalerite and galena

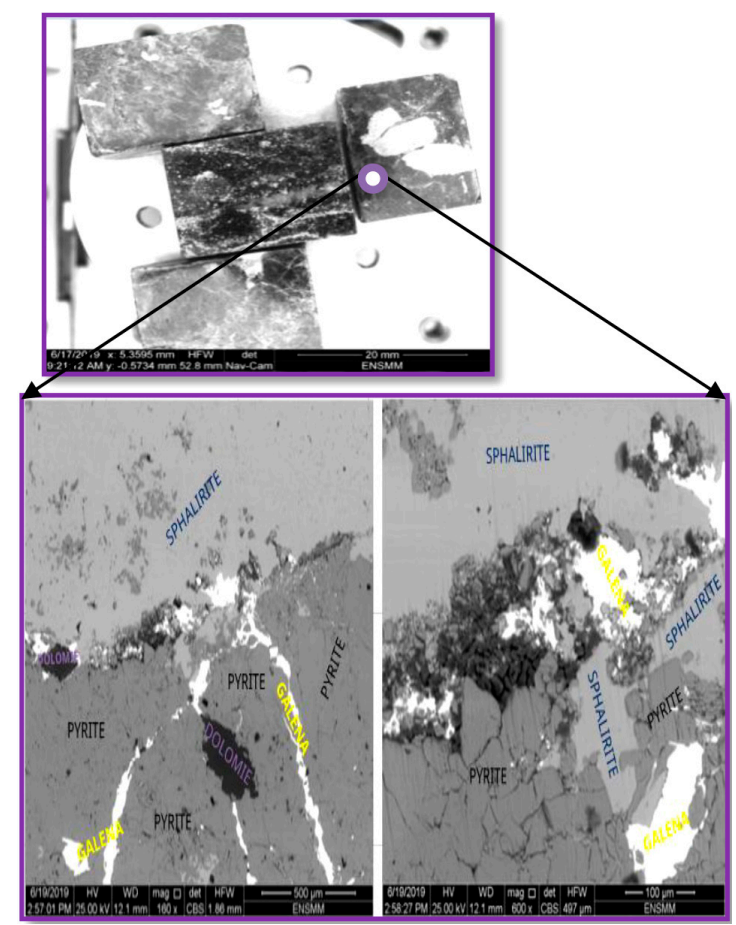

Fig. 5. Coating of sphalerite with galena, pyrite, dolomite and fine-grained quartz

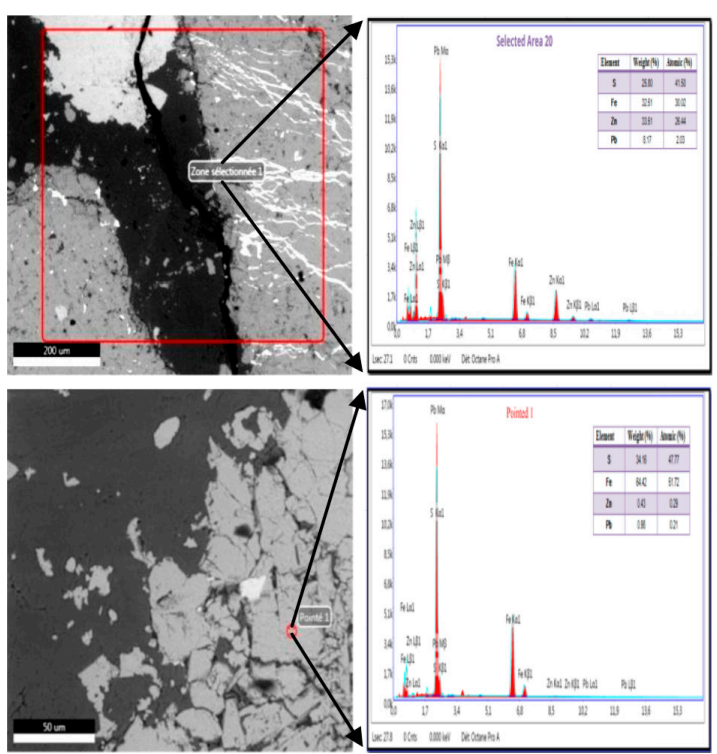

Fig. 6. Micrograph $(S E M+E D X)$ of different surface samples 


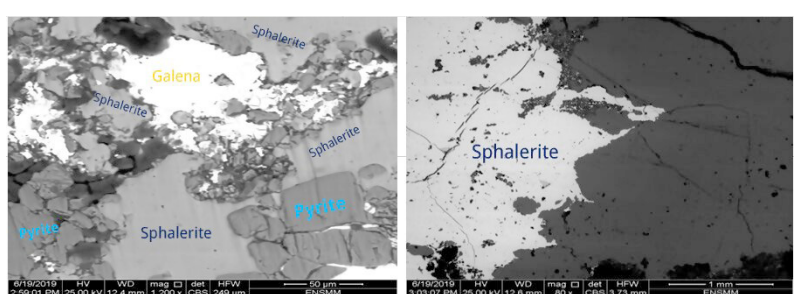

Fig. 7. SEM views: Ore microscope revealing the association between sphalerite and ather different minerals

Flotation processing results. After the lead-zinc ore flotation process, the scraped concentrate as well as the rejects from the processing operations is subjected to X-ray diffraction and X-ray fluorescence analyses, to control the desired concentrate content, which is estimated to be more than $50 \%$ Zinc, and to control the content of metals in the discharges, before they are released into the environment. The results obtained are shown in Figs. 8, 9. The diagram below illustrates the concentration by level (Fig. 10). These results confirm the effectiveness of the enrichment method applied.

Conclusion. The results obtained by the particle size analysis make it possible to select the richest slice of the recoverable mineral sphalerite; so do the theoretical dimensions of the particles, during a total and optimal release of the constituents, that the one finds in the fine grain size classes $[-1+0.053] \mathrm{mm}$, with a maximum zinc content $10 \%$.

However, the results of the mineralogical characterization by Optical Microscopy (OM) and Scanning Electron Microscopy (SEM) reveal a very varied and irregular texture of the ore, consisting mainly of sulphides (sphalerite, galena, pyrite, marcasite), associated with carbonate gangue, mainly dolomite and calcite, also the coating of the sphalerite (small crystals) by bulky spots of pyrite or dolomite.

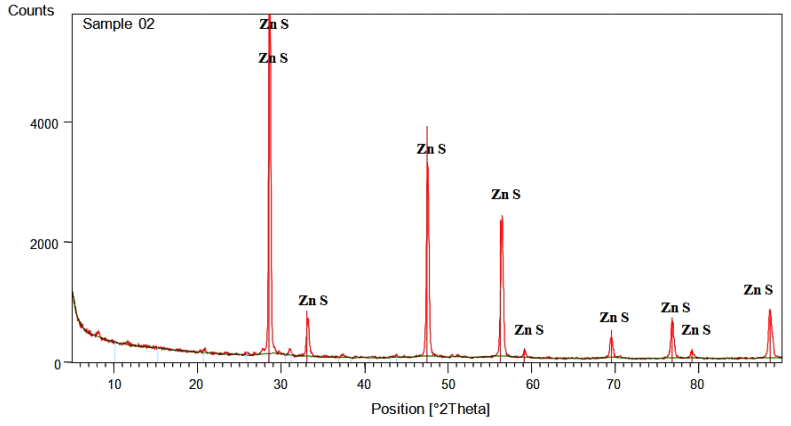

Fig. 8. Flotation results, $X$-ray diffraction spectrum (XRD) of $Z n S$

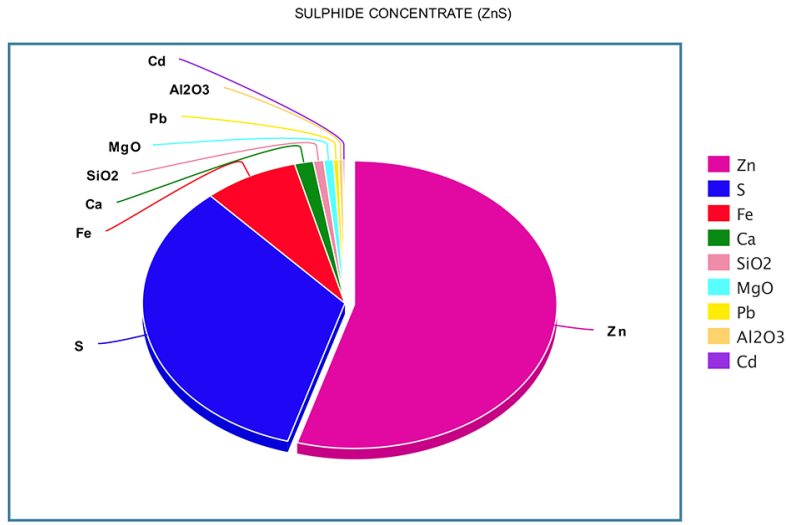

Fig. 9. Chemical compositions of sphalerite concentrate

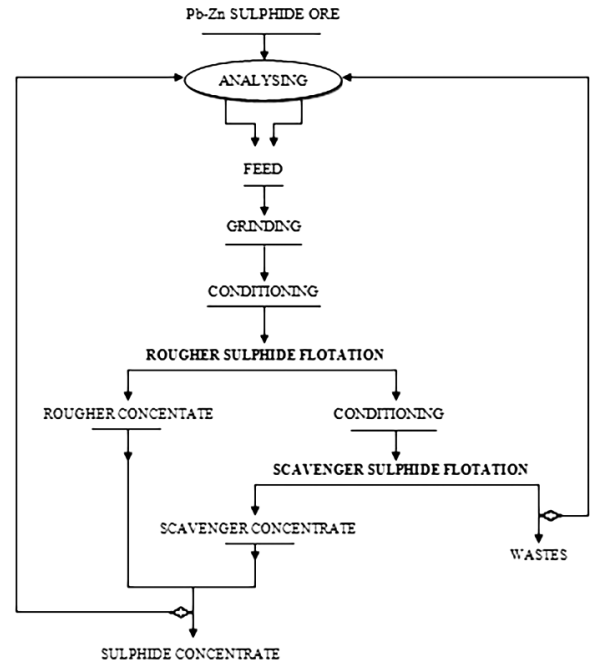

Fig. 10. Schematic diagram of the processing of sulphide leadzinc ore by flotation

The preparation of a very stable paste for the flotation treatment process is carried out using the following reagents: the $\mathrm{CuSO}_{4}$ activator, the PAX collector, the $\mathrm{CaO}$ regulator and the pine oil foamed, along with a $\mathrm{pH}$ modifier, between 10.5 and 12 . These conditions enabled us to improve the concentrate content in order to reach more than $50 \% \mathrm{Zn}$ in the form of sphalerite $(\mathrm{ZnS})$.

The experimental studies carried out on the characterization (mineralogical, particle size and chemical) and on the conditions of the pulp, as well as the selectivity of the separation, are well increased the content of sulphide minerals by foam flotation, which adapts more efficiently processing requirements to give maximum recovery and economically appropriate content ( $54 \% \mathrm{Zn}$ concentrate). Finally, the diagram that we have proposed shows all the stages and conditions to reach and obtain valid results in line with the objectives set in this experimental work.

Acknowledgments. Laboratory managers and engineers of Tebessa University, Annaba University, Bejaia University, and Higher School of Mining and Metallurgy- Annaba, Algeria.

Dr. Merdas Brahim, Faculty of geology, Badji Mokhtar University - Annaba, Algeria; for their help in carrying out this scientific research.

Funding. The present research work was financed and supported by the Directorate General for Scientific Research and Technological Development (DGRSDT) of Algeria. The authors also appreciate the unknown referee's valuable and profound comments.

\section{References.}

1. Wang, H., Wen, S., Han, G., \& Feng, Q. (2019). Effect of copper ions on surface properties of $\mathrm{ZnSO} 4$-depressed sphalerite and its response to flotation. Separation and Purification Technology, 228, 115756. https://doi.org/10.1016/i.seppur.2019.115756.

2. Jia, Y., Huang, X., Huang, K., Wang, S., Cao, Z., \& Zhong, H. (2019). Synthesis, flotation performance and adsorption mechanism of 3-(ethylamino)-N-phenyl-3-thioxopropanamide onto galena/ sphalerite surfaces. Journal of Industrial and Engineering Chemistry, 77, 416-425. https://doi.org/10.1016/j.jiec.2019.05.005.

3. Deng, J. S., Mao, Y. B., Wen, S. M., Liu, J., Xian, Y. J., \& Feng, Q.C. (2015). New influence factor inducing difficulty in selective flotation separation of $\mathrm{Cu}-\mathrm{Zn}$ mixed sulfide minerals. International Journal of Minerals, Metallurgy, and Materials, 22(2), 111-115. https://doi.org/10.1007/s12613-015-1050-x.

4. Fontbote, L., Kouzmanov, K., Chiaradia, M., \& Pokrovski, G. S. (2017). Sulfide minerals in hydrothermal deposits. Elements, 13(2), 97-103. https://doi.org/10.2113/gselements.13.2.97.

5. Lai, H., Deng, J., Fan, G., Xu, H., Chen, W., Li, S., \& Huang, L. (2019). Mechanism study of Xanthate adsorption on sphalerite/mar- 
matite surfaces by TOF-SIMS analysis and flotation. Minerals, 9(4), 205. https://doi.org/10.3390/min9040205.

6. Noirant, G., Benzaazoua, M., Kongolo, M., Bussière, B., \& Frenette, K. (2019). Alternatives to Xanthate collectors for the desulphurization of ores and tailings: Pyrite surface chemistry. Colloids and Surfaces A: Physicochemical and Engineering Aspects, 577, 333-346. https://doi.org/10.1016/j.colsurfa.2019.05.086.

7. Peltoniemi, M., Kallio, R., Tanhua, A., Luukkanen, S., \& Perämäki, P. (2020). Mineralogical and Surface Chemical Characterization of Flotation Feed and Products after Wet and Dry Grinding. Minerals Engineering, 156, 106500. https://doi.org/10.1016/i.mineng.2020.106500.

8. Wei, Z., Wang, H., Xue, C., \& Zeng, M. (2020). Selective depression of sphalerite by combined depressant $\mathrm{K}_{3}\left[\mathrm{Fe}(\mathrm{CN})_{6}\right], \mathrm{ZnSO}_{4}$, and $\mathrm{Na}_{2} \mathrm{CO}_{3}$ in $\mathrm{Pb}-\mathrm{Zn}$ sulfide flotation separation. Chemical Papers, 74(2), 421-429. https://doi.org/10.1007/s11696-019-00884-w.

9. Ejtemaei, M., \& Nguyen, A. V. (2017). Characterization of sphalerite and pyrite surfaces activated by copper sulphate. Minerals Engineering, 100, 223-232. https://doi.org/10.1016/j.mineng.2016.11.005.

10. Issaad, M., Boutaleb, A., \& Kolli, O. (2017). Mine Waste at The Kherzet Youcef Mine: Environmental Characterization. EGUGA, 10069. 11. Nakache, R., Boukelloul, M. L., Bouhedja, A., \& Fredj, M. (2019). Stability analysis of the pillars of the underground mine Chaàbet el-Hamra, Algeria by analytical and numerical methods. Naukovyi Visnyk Natsionalnoho Hirnychoho Universytetu, (2). https://doi. org/10.29202/nvngu/2019-2/1

12. Bellouche, M. (2016). Schema hydrogeologique possible de la mine de Kherzet Youssef (Nord-Est Algerian). Sciences \& Technologie. $D$, Sciences de la terre, 73-80.

13. Zhang, X., Han, Y., \& Kawatra, S. K. (2020). Effects of grinding media on grinding products and flotation performance of sulfide ores. Mineral Processing and Extractive Metallurgy Review, 1-12. https://doi. org/10.1080/08827508.2019.1692831.

14. Bai, X., Wen, S., Liu, J., \& Lin, Y. (2018). Response surface methodology for optimization of copper leaching from refractory flotation tailings. Minerals, 8(4), 165. https://doi.org/10.3390/min8040165.

15. Wang, G., Nguyen, A. V., Mitra, S., Joshi, J. B., Jameson, G. J., \& Evans, G. M. (2016). A review of the mechanisms and models of bubble-particle detachment in froth flotation. Separation and Purification Technology, 170, 155-172. https://doi.org/10.1016/j.seppur.2016.06.041. 16. Shengo, M. L., Kime, M. B., Mambwe, M. P., \& Nyembo, T. K. (2019). A review of the beneficiation of copper-cobalt-bearing minerals in the Democratic Republic of Congo. Journal of Sustainable Mining, 18(4), 226-246. https://doi.org/10.1016/i.jsm.2019.08.001.

17. Bu, X., Xie, G., Peng, Y., Ge, L., \& Ni, C. (2017). Kinetics of flotation Order of process, rate constant distribution and ultimate recovery. Physicochemical Problems of mineral processing, 53. https:// doi.org/10.5277/ppmp170128.

18. Kaniki, A. T., \& Tumba, K. (2019). Management of mineral processing tailings and metallurgical slags of the Congolese copper belt: Environmental stakes and perspectives. Journal of Cleaner Production, 210, 1406-1413. https://doi.org/10.1016/j.jclepro.2018.11.131.

\section{Склад і переробка сульфідних свинцево- цинкових руд шахти Шаабет Ель-Хамра (Сетіф, Алжир)}

1 - Лабораторія гірничої справи, Університет Ларбі Тебеci, м. Тебесса, Алжир, e-mail: m.bourourou@univ-tebessa.dz 2 - Університет Ларбі Тебесі, м. Тебесса, Алжир

3 - Центр Екологічних Досліджень ЦЕД, м. Аннаба, Алжир

Мета. Для більш повного вилучення металу й підвищення ефективності його переробки необхідні дані про гранулометричний і речовинний склад руди для розробки флотаційної технології ії збагачення.

Методика. У даній експериментальній роботі виконані мінералогічний, хімічний і гранулометричний аналіз руди. Аналізи були виконані за допомогою скануючої електронної мікроскопії з енергодисперсійною спектроскопією (СЕМ/ЕДС), рентгенодифракційного методу (РДМ), оптичної мікроскопії (ОМ), аналізом гранулометричних фракцій (АГМФ) і рентгенівської флуоресценції (РФ). Ці аналізи виконані на зразках свинцево-цинкових проб різних розмірів і підготовленого дрібного порошку руди; вміст цинку $(\mathrm{Zn})$ у пробах становить близько $5 \%$

Результати. Результати, отримані за допомогою мінералогічного та гранулометричного аналізу, показують дуже різноманітну й нерівномірну структуру руди, що складається, в основному, із сульфідів (сфалерит, галеніт, пірит, марказит), що пов'язані з карбонатною порожньою породою, в основному доломітом і кальцитом. Теоретичні розміри частинок, що виявлені у дрібних класах крупності, складають $[-1+0,053]$ мм. Крім того, збагачення методом пінної флотації з використанням наступних реагентів: активатор $\left(\mathrm{CuSO}_{4}\right)$, колектор (PAX), регулятор $(\mathrm{CaO})$ і спінювач (соснове масло) разом із модифікатором при рН від 10,5 до 12 (оптимально 11,8) підвищують зміст сульфідних мінералів і вихід концентрату сфалериту (ZnS) із максимальним вилученням і економічно доцільним вмістом цинку (концентрат 54 \% Zn).

Наукова новизна. У лабораторних умовах отримані більш точні дані характеристики руди, що дозволяє оптимізувати процес переробки сульфідної свинцево-цинкової руди. Отримані більш точні довідкові матеріали для фахівців, дослідників і металургів в області видобутку корисних копалин у цілому та при переробці поліметалічних свинцево-цинкових руд зокрема.

Практична значимість. Показана економічна доцільність отримання корисних мінералів (концентрат цинку та інших сульфідів) з різних видів сировини. Найкрашим методом збагачення свинцево-цинкових руд є флотація, але вона вимагає для досягнення високих результатів постійного контролю технологічних параметрів.

Ключові слова: свинцево-цинкова руда, аналізи CEM/ ЕРС, сфалерит, флотація, переробка корисних копалин, оптимізація

Recommended for publication by Dr. Torkia Tahri. The manuscript was submitted 05.02.21. 